\title{
IMPACT OF MOLECULAR METHOD FOR THE DIAGNOSIS OF ACUTE BACTERIAL MENINGITIS IN A TERTIARY HEALTH CARE CENTRE IN NORTH INDIA
}

\author{
M.S. Raza', *B.K. Das'1, V. Goyal', R. Lodha', R. Chaudhry'1, S. Sood', \\ V. Sreenivas ${ }^{1}$, D. Nair ${ }^{2}$, S. Mohapatra', H. Gautam ${ }^{1}$, A. Kapil' \\ 1 - ALL INDIA INSTITUTE OF MEDICAL SCIENCES, NEW DELHI, INDIA \\ 2 - VMC, SAFDARJUNG HOSPITAL, INDIA
}

Background. Acute bacterial meningitis is one of the significant infectious diseases that add an immense burden to the health system. Proper management of meningitis is an invincible need to overcome the severe consequences.

Objectives. The aim of the study is detection of the etiological agents of acute bacterial meningitis by PCR.

Methods. Total 267 CSF samples collected from suspected bacterial meningitis cases were processed for the detection of S. pneumoniae, H. influenzae, N. meningitidis, E. coli and Group B streptococci by conventional and molecular diagnosis method. CSF was inoculated on Blood, chocolate and MacConkey agar plates and incubated at $37^{\circ} \mathrm{C}$ for 24-48 hrs. Bacteria grown were identified by Matrix assisted laser desorption/ionization time of flight (MALDI-TOF). Multiplex PCR of the enlisted bacteria was performed using DNA extracted from CSF by DNA extraction kit (Qiagen, USA).

Results. 5 (1.87\%) out of the total 267 CSF samples were culture positive (3 S. pneumoniae and 2 E. coli) and $28(10.49 \%)$ had detectable DNA by conventional PCR. Out of these 28 samples, 20 (71.43\%) were S. pneumoniae and 8 (28.57\%) were E. coli. 15 (53.57\%) out of total S. pneumoniae were present in children below 5 years of age. Similarly, E. coli was predominant in neonates. Sensitivity and specificity of the PCR was $100 \%$ and $95-98 \%$ respectively.

Conclusions. Streptococcus pneumoniae is the commonest cause of community acquired bacterial meningitis in children below five years of age. Hence, for the promising outcome, PCR should be implemented for the diagnosis of acute bacterial meningitis.

KEY WORDS: cerebrospinal fluid (CSF); acute bacterial meningitis; PCR; MALDI-TOF.

\section{Introduction}

Bacterial meningitis is one of the dangerous infectious diseases of central nervous system (CNS). Meningitis is an inflammation of delicate membrane known as meninges covering brain and spinal cord and marked by intense headache, fever and nuchal rigidity. Despite advances in treatment, acute bacterial meningitis (ABM) is the major cause of mortality and morbidity in developed countries as well as in developing ones [1]. In India and other developing countries mortality rate varies $16-32 \%$ [2-5]. Individuals with suspected meningitis require prompt diagnosis and treatment. Delay in management can result in poor outcome of the disease [6].

The most common bacteria causing ABM are Streptococcus pneumoniae, Haemophilus influenzae, Neisseria meningitidis, Listeria *Corresponding author: Dr. Bimal Kumar Das, Department of Microbiology, All India Institute of Medical Sciences, New Delhi, India.

Email: tezpur.bimal@gmail.com monocytogenes, Group B Streptococci and E. coli [7]. Etiological agents of ABM vary globally depending on age, geographical area and immune status $[8,9]$. Hence, there is need for regularly reviewing of bacterial meningitis.

Culture is considered as the 'Gold standard' for the diagnosis of acute bacterial meningitis as well as equally important for antibiotic susceptibility testing of the causative agents that account for treatment [10]. However, it takes longer for identification of the pathogens and its outcome is influenced by intake of antibiotics prior to lumber puncture and number of bacteria (CFU/ml) present in the CSF. To overcome this diagnostic glitch, polymerase chain reaction (PCR) is gaining momentum for a rapid diagnosis of ABM [11-17]. Hence, this experiment have been designed and performed to detect the etiological agents of community acquired bacterial meningitis by molecular method as PCR does not rely on viability of the organism. 


\section{Methods}

A perspective study was designed and carried out at the Department of Microbiology, All India Institute of Medical Sciences, New Delhi, India. Total 267 cerebrospinal fluids (CSF) samples from suspected acute bacterial meningitis cases were collected in March, 2015 April, 2018. All samples were processed for cytological, biochemical, Microbiological (Gram stain, Latex agglutination and culture) and molecular examination. CSF was centrifuged at $10,000 \mathrm{rpm}$ for 10 minutes. Sediment was used for Gram stain and culture. Blood, chocolate and Mac-conkey agar plates were used for growth of the bacteria. After inoculation, the plates were incubated at $37{ }^{\circ} \mathrm{C}$ for $24-48 \mathrm{hrs}$ with $5 \% \mathrm{CO}_{2}$. Isolates grown on the culture plates were identified by MALDI-TOF (Vitek MS Biomerieux, France). The isolates were further processed for antibiotic susceptibility tests. Nosocomial infection was defined as a positive bacterial infection that was not present at the time of hospital admission or clinical evidence of an infection no sooner than 48 hours after admission. Remaining patients were considered to have community acquired infection.

Identification of isolates by MALDI-TOF. For identification of the bacteria, a single bacterial colony was taken, and the smear was made on the MALDI-TOF slide with the help of wooden stick and $0.5 \mu \mathrm{l}$ matrix (a-cyano-4hydroxycinnamic acid) was added. The slide was kept in air at a room temperature for 5 minutes to dry and finally slide was kept in the MALDI-TOF machine (VITEK MS Biomerieux, France) for acquisition and identification. The isolates identified were further processed for antibiotic susceptibility test.

Antibiotics susceptibility test. Mueller Hinton Agar was used to perform an antibiotic susceptibility test. The isolate was inoculated in $0.5 \%$ peptone water and incubated at $37{ }^{\circ} \mathrm{C}$ for 2 hrs. Turbidity was compared with 0.5 McFarland solutions so that bacterial count to be $>10^{5} \mathrm{CFU} / \mathrm{ml}$. Antibiotics used were amikacin $(10 \mu \mathrm{g})$, co-trimoxazole $(25 \mu \mathrm{g})$, cephotaxime $(30 \mu \mathrm{g})$, ceftazidime $(30 \mu \mathrm{g})$, ceftriaxone $(30 \mu \mathrm{g})$, ciprofloxacin $(30 \mu \mathrm{g})$, erythromycin $(30 \mu \mathrm{g})$, penicillin G (10units), piperacillin + tazobactam $(100 / 10 \mu \mathrm{g})$, imipenem $(10 \mu \mathrm{g})$, Netilmicin $(30 \mu \mathrm{g})$, chloramphenicol $(30 \mu \mathrm{g})$ and vancomycin $(30 \mu \mathrm{g})$. The antibiotic discs were obtained from Hi Media Laboratories, Mumbai, India. Antibiotic susceptibility results were interpreted as per CLSI guideline. The Escherichia coli ATCC25922 and Staphylococcus aureus ATCC25923 strains were used for quality control.

Latex agglutination test (LAT). A supernatant of the centrifuged CSF was used for detection of soluble bacterial antigen of Streptococcus pneumoniae, Neisseria meningitidis A, B, C, and W135, Streptococcus agalactiae, Escherichia coli, and Haemophilus influenzae type $B$ by latex agglutination test (LAT) following manufacturer's instructions. The Directigen ${ }^{\mathrm{TM}}$ Meningitis combo Kit (BD, USA) was used for the LAT.

Extraction of DNA. Extraction of DNA from CSF samples was carried out using the Mini DNA extraction Kit (Qiagen, USA) following manufacturer's instructions. DNA was eluted in $100 \mu \mathrm{l}$ elution buffer and stored at $-20^{\circ} \mathrm{C}$ for future use in the experiment.

Primer design and PCR conditions. For detection of S. pneumoniae, $H$. influenzae and $N$. meningitidis semi-nested multiplex PCR was designed. However, for E. coli \& Group B streptococcus the Multiplex PCR was done. Primers were designed accordingly that is presented in Table 1.

Table1. Sequence of primers used in this study

\begin{tabular}{|c|c|c|c|c|c|}
\hline \multirow{4}{*}{\multicolumn{2}{|c|}{\begin{tabular}{l|l|} 
岂 & $\begin{array}{l}\text { Universal } \\
\text { 岂 }\end{array}$ \\
Primer
\end{tabular}}} & Target Gene & Primer & $\begin{array}{l}\text { Amplicon } \\
\text { length (bp) }\end{array}$ & Reference \\
\hline & \multicolumn{5}{|c|}{ Seminested Multiplex PCR } \\
\hline & & U3 (16S rRNA) & 5'-GTG CCT GCA GCC GCG GTA AT-3' & \multirow[t]{2}{*}{1000} & \\
\hline & & U8 (16S rRNA) & 5'-AAG GAG GGG TGT GTAC-3' & & \\
\hline \multirow{3}{*}{ 苨 } & S. pneumoniae & ply & 5'-GTA CAA CGA GTC GCA AGC-3' & 293 & \\
\hline & H. influenzae & bex & 5'-CCT AAG AAG AGA TCG AG-3' & 543 & \\
\hline & N. meningitidis & ctr & 5'-TGT TGC GCA ACC TGA TTG-3' & 710 & \\
\hline \multirow{5}{*}{ 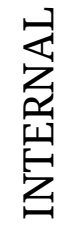 } & \multicolumn{4}{|c|}{ Multiplex PCR } & $\begin{array}{c}\text { Chakrabarti P } \\
\text { et al, 2009 } \\
{[18]}\end{array}$ \\
\hline & \multirow[t]{2}{*}{ E. coli } & \multirow[t]{2}{*}{ 16S rRNA } & 5'-TGC CTG ATG GAG GGG GAT AA-3' & \multirow[t]{2}{*}{776} & \multirow[t]{2}{*}{ This study } \\
\hline & & & 5'-TTT AAC CTT GCG GCC GTA CT-3' & & \\
\hline & \multirow[t]{2}{*}{ S. agalactiae } & \multirow[t]{2}{*}{ sip } & 5'-ACA ACG GAA GGC GCT ACT GTT C-3' & \multirow[t]{2}{*}{255} & \multirow{2}{*}{$\begin{array}{c}\text { Bergh K et al, } \\
2004 \text { [19] }\end{array}$} \\
\hline & & & 5'-ACC TGG TGT TTG ACC TGA ACT A-3' & & \\
\hline
\end{tabular}


Amplification of DNA extracted from the CSF. The PCR mixture $(25 \mu \mathrm{l})$ contained $1 \times$ PCR buffer $2.5 \mu \mathrm{l}$ with $2.5 \mathrm{mM} \mathrm{Mgcl}{ }_{2}, 0.5 \mu \mathrm{l}$ dNTPs (10mM each), $0.25 \mu \mathrm{l} \mathrm{Taq} \mathrm{polymerase} \mathrm{(Promega,}$ 500U) \& Primer $0.2 \mu \mathrm{l}(10 \mu \mathrm{M}$ each) for seminested multiplex PCR. However, for multiplex $\mathrm{PCR}$, primer concentration used was $1 \mu \mathrm{l}(10 \mu \mathrm{M}$ each) and $2.5 \mu \mathrm{l}$ of the target DNA. Finally, the volume of the PCR mixture was adjusted by adding milli $Q$ water. PCR was performed in the Thermocycler (Agilent Technologies, Surecycler 8800 , USA) with the following cycling condition for multiplex $P C R$, i.e. initial denaturation at $95^{\circ} \mathrm{C}$ for $5 \mathrm{~min}$, denaturation at $95^{\circ} \mathrm{C}$ for $1 \mathrm{~min}$, Annealing $55^{\circ} \mathrm{C}$ for $30 \mathrm{sec}$, extension $72{ }^{\circ} \mathrm{C}$ for $30 \mathrm{sec}$ and final extension at $72{ }^{\circ} \mathrm{C}$ for $10 \mathrm{~min}$ with $4{ }^{\circ} \mathrm{C}$ holding temperature, the number of cycles was 35 . After amplification of the bacterial DNA, gel electrophoresis of the PCR product was run for 30 minutes in 1.5\% agarose with ethidium bromide and visualize under UV fluorescence to check the product size. Representative Image of the Gel electrophoresis is presented in Fig. 1.

Statistical analysis. of the tests was performed by the Wilcoxon Singed-rank test. Sensitivity, specificity, positive predictive value (PPV) and negative predictive value (NPV) were evaluated.

Ethical Approval. The study was approved by the Institute Ethics Committee of All India Institute of Medical Sciences, New Delhi (No: IESC/T-20)

\section{Results}

The finding of the study was interpreted and correlated with the etiological agents of ABM in all age group (0 days-84 years) with conventional and molecular techniques. Out of total 267 cases of suspected meningitis patients, $194(72.60 \%)$ were male and $73(27.34 \%)$ were female. The main clinical feature shown by the patients were fever 258 (96.63\%), headache $210(78.65 \%)$ and altered sensorium 181 (67.79\%) details are given in Table 2.

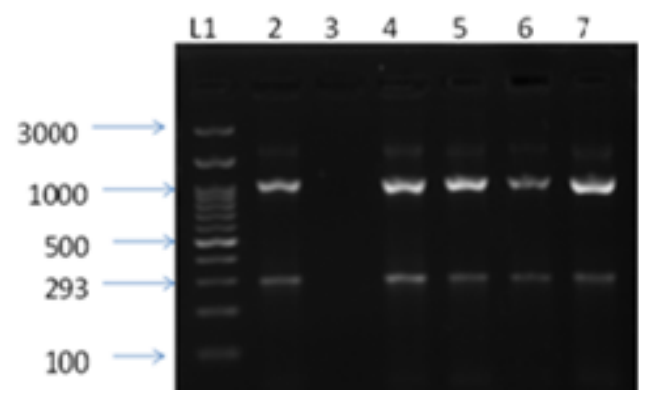

Fig.1. A gel image of PCR product of S. pneumoniae in $1.5 \%$ agar.

$L_{1}=$ Ladder, $L_{2}=$ Positive control, $L_{3}=$ Negative control $\& L_{4,5,6,7}=$ CSF sample.

The CSF glucose and protein level of the majority of the patients were $<45 \mathrm{mg} / \mathrm{dl}$ and $>55 \mathrm{mg} / \mathrm{dl}$ respectively. Out of 267 CSF samples, $5(1.87 \%)$ were proved to be positive by culture. Among these 5 isolates, $3(60 \%)$ were S. pneumoniae and $2(40 \%)$ were E. coli. Similarly, total 28 (10.49\%) bacteria were detected by conventional PCR (CPCR) as the culture positive bacteria were also positive by PCR; out of 23 bacteria detected by PCR only, 6 (26.09\%) were E. coli and $17(73.91 \%)$ were S. pneumoniae. Main cases of the organisms revealed were of the age group of 0-5 yearsold. Likewise, 4 (50\%) cases of $E$. coli were revealed in neonates. In case of S. pneumoniae, 15 (53.57\%) isolates were revealed in children below 5 years of age. The details of distribution of bacteria revealed are presented in Table 3.

Latex agglutination test (LAT) was used to detect the bacterial soluble antigen of the common etiological agents of acute bacterial meningitis: Streptococcus pneumoniae, Neisseria meningitidis A, B, C \& W135, Streptococcus agalactiae, Escherichia coli, and Haemophilus influenzae type B. However, only S. pneumoniae and E. coli was detected by the LAT in this study. The LAT has detected more organisms than the culture. Total 15 isolates were detected by the LAT. Out of 15 LAT positive isolates 10 (5 S. pneumoniae and 5 E. coli) were positive by the LAT only. However,

Table 2. Demographic details of the meningitis patients

\begin{tabular}{|l|c|}
\hline \multicolumn{1}{|c|}{ Clinical Features } & Number of patients \\
\hline Fever & $258(96.63 \%)$ \\
\hline Headache & $210(78.65 \%)$ \\
\hline Nuchal rigidity & $57(21.34 \%)$ \\
\hline Altered sensorium & $181(67.79 \%)$ \\
\hline Nausea/Vomiting & $54(20.24 \%)$ \\
\hline Kernig's and Brudzinski's sign & $51(19.10 \%)$ \\
\hline Bulging anterior fontanelle & $32(11.98 \%)$ \\
\hline
\end{tabular}


Table 3. Age wise distribution of the isolates detected from CSF

\begin{tabular}{|c|c|c|c|c|c|c|c|c|}
\hline \multirow[b]{2}{*}{ Isolates } & \multirow{2}{*}{$\begin{array}{c}\text { Methods } \\
\text { of detection }\end{array}$} & \multicolumn{6}{|c|}{ Age group } & \multirow[b]{2}{*}{ Total } \\
\hline & & Neonates & $\begin{array}{c}1-3 \\
\text { months }\end{array}$ & $\begin{array}{c}-24 \\
\text { months }\end{array}$ & 2-5 yrs & $5-50$ yrs & $>50$ yrs & \\
\hline \multirow[t]{2}{*}{ E. coli } & Culture & 01 & - & - & - & - & 01 & 02 \\
\hline & CPCR & 03 & 02 & - & - & - & 01 & 06 \\
\hline \multirow[t]{2}{*}{ S. pneumoniae } & Culture & - & - & 01 & 01 & 01 & - & 03 \\
\hline & CPCR & - & 02 & 07 & 04 & 02 & 02 & 17 \\
\hline \multicolumn{2}{|c|}{ Total } & 04 & 04 & 08 & 05 & 03 & 04 & 28 \\
\hline
\end{tabular}

3 S. pneumoniae and 2 E. coli that were culture positive were also positive by the LAT.

Taking culture as gold standard, the sensitivity, specificity, positive predictive value and negative predictive value were evaluated. Sensitivity and specificity of CPCR for S. pneumoniae and $E$. coli were found in $100 \%$ and $95-98 \%$ cases, respectively, with $95 \% \mathrm{CI}$ that is presented in Table 4.
The antibiotic susceptibility test was performed for E. coli and S. pneumoniae detected from CSF by culture. Most of the antibiotics tested were susceptible to $S$. pneumoniae $(100 \%)$. One $(33.36 \%)$ S. pneumoniae showed resistance to co-trimoxazole. For $E$. coli, the most susceptible antibiotic was amikacin (100\%) followed by colistin (100\%) and imipenem (100\%).

Table 4. Sensitivity, specificity, PPV, NPV of CPCR comparing with culture

\begin{tabular}{|l|c|c|c|c|}
\hline \multirow{3}{*}{ Statistics } & \multicolumn{3}{|c|}{ Conventional PCR } \\
\cline { 2 - 5 } & \multicolumn{2}{|c|}{ E. coli (N=6) } & S. pneumoniae (N=17) \\
\cline { 2 - 5 } & Value & with 95\% CI & Value & with 95\% CI \\
\hline Sensitivity & $100 \%$ & $15.81 \%-100 \%$ & $100 \%$ & $28.24 \%-100 \%$ \\
\hline Specificity & $98.28 \%$ & $96.29 \%-99.36 \%$ & $95.26 \%$ & $95.53 \%-97.22 \%$ \\
\hline PPV & $25 \%$ & $13.10 \%-42.42 \%$ & $15 \%$ & $9.99 \%-21.92 \%$ \\
\hline NPV & $100 \%$ & - & - & $95.30 \%$ \\
\hline Accuracy & $98.29 \%$ & $96.31 \%-99.37 \%$ & $95.30 \%$ & $92.59 \%-97.24 \%$ \\
\hline
\end{tabular}

\section{Discussion}

Community acquired acute bacterial meningitis is an urgent health issue as most of the infection occurs in children below 5 years of age. In this study, total 267 CSF samples were included irrespective of the age limit. Of the total number of CSF, only 5 (1.87\%) were found positive by culture for different etiological agents of community acquired bacterial meningitis. A study conducted by Zahra B. H et al. has shown culture positivity $2.5 \%$ [20]. Positivity of culture decreases $60-70 \%$ in case of CSF collected after administration of antibiotics [21]. In our study, low culture positivity may be due to intake of antibiotics prior to lumber puncture as our hospital is a referral center where majority of the patients admitted had already been administered with various antibiotics before getting admitted.

We detected 28 (10.14\%) positive CSF by CPCR which were almost $10 \%$ more than the culture positives. Our finding is concurrent with the finding (11.76\%) shown by Nour M et al. [22] but less than the finding by Zahra B. $\mathrm{H}$. et al. and Chokrabarty P. et al. who have reported $15 \%$ and $19.8 \%$ positivity by mPCR respectively $[18,20]$. Low positivity may be due to difference in sample size and organisms detected. Sensitivity and specificity of convention PCR was found $100 \%$ and $95-98 \%$ respectively for $E$. coli and S. pneumoniae with $95 \%$ CI. Finding was concurrent with the findings of Wu et al. [23].

In children below 1-24 months of age S. pneumoniae $10(50 \%)$ was the main organism. However, E. coli 4 (50\%) were found in neonates that was also a significant finding as E. coli and S. agalactiae are the major pathogens of the neonates $[24,25]$. We have detected total 20 S. pneumoniae, $15(75 \%)$ of which were in those less than 5 years of age. Likewise, out of these 15 cases, 8 (53.3\%) were detected in those 3-24 months of age. More number of $S$. pneumoniae in children below 5 years of age was reported from India [26, 27]. However, 1 previous study conducted in 1999 by ISIB has reported $H$. influenzae as the main cause of bacterial menin- 
gitis prior to the introduction of pentavalent vaccines [28].

In our study, only E. coli and S. pneumoniae were detected among the etiological agents of community acquired acute bacterial meningitis that may be a result of implementation of the Hib vaccination in national immunization program in India. $\boldsymbol{H}$. influenzae detection rate has decreased drastically in recent times. Similarly, in India, incidence of $N$. meningitidis increased greatly during the epidemics and the epidemic cycle of N. meningitidis is at an interval of 15-20 years. Last episode of $N$. meningitidis epidemics was in 2005 [29].

Antibiotic susceptibility test result showed that most of the antibiotics used were susceptible to S. pneumoniae. One (33.3\%) S. pneumoniae out of 3 was resistance to co-trimoxazole. However, no penicillin resistance S. pneumoniae was found. Similarly, amikacin, colistin and imipenem were the most susceptible $(100 \%)$ antibiotics for $E$. coli though ciprofloxacin has shown $(50 \%)$ resistance followed by cefo + salbactam (50\%).

\section{Conclusions}

Acute bacterial meningitis is a severe medical emergency and S. pneumoniae is still the a major cause of community acquired bacterial meningitis in children. Molecular diagnosis is gaining momentum for a rapid detection of etiological agents with high sensitivity and specificity since it is unaffected by viability of the organisms. Hence, PCR should be implemented in the diagnosis to overcome the dependency on conventional method.

\section{Conflict of Interest}

The authors declare no conflict of interest. Acknowledgements

Authors acknowledge the Indian Council of Medical Research (ICMR), New Delhi

\section{Funding}

This work was supported by Grant of Institute Research fund. Institute Grant No: 8-297/A-297/2014/RS

\section{Authors Contributions}

M.S. Raza-conceptualization, investigation, writing (original draft), B.K. Das - cconceptualization, project administration, resources, supervision (review and editing), V. Goyal, R. Lodha, R. Chaudhry, S. Sood, D. Nair, S. Mohapatra, A. Kapil - cconceptualization, supervision, writing (review and editing), H. Gautam - conceptualization, writing (review and editing), V. Sreenivas - formal analysis, visualization writing, data curation.

\title{
МОЛЕКУЛЯРНІ МЕТОДИ ДІАГНОСТИКИ ГОСТРОГО БАКТЕРІАЛЬНОГО МЕНІНГІТУ НА ТРЕТИННОМУ РІВНІ НАДАННЯ МЕДИЧНОЇ ДОПОМОГИ У ЛІКАРНЯХ ПІВНІЧНОЇ ІНДІї
}

\author{
M. S. Raza', B. K. Dasi, V. Goyal', R. Lodha', R. Chaudhry', S. Sood', \\ V. Sreenivas', D. Nair'2, S. Mohapatra', H. Gautam'1', A. Kapil'1 \\ 1 - ALL INDIA INSTITUTE OF MEDICAL SCIENCES, NEW DELHI, INDIA \\ 2 - VMC, SAFDARJUNG HOSPITAL, INDIA
}

Вступ. Гострий бактеріальний менінгіт - одне з найбільш небезпечних інфекційних захворювань, що слугує додатковим тягарем для системи охорони здоров'я. Відповідне лікування - необхідна умова для попередження та лікування тяжких наслідків хвороби.

Мета дослідження - встановлення етіологічних чинників гострого бактеріального менінгіту за допомогою ПЛР.

Методи. Загалом було відібрано 276 зразків спинномозкової рідини (CMP) від пацієнтів з підозрою на бактеріальний менінгіт для визначення його основних збудників S. pneumoniae, H. influenzae, N. meningitidis, E. coli ma cтрептококів групи В типовим способом та за допомогою методів молекулярної діагностики. Для проведення культурального дослідження зразків СМР використовували живильні середовища: кров'яний агар, шоколадний агар, середовище МакКонкі. Зразки інкубували при $37^{\circ} \mathrm{C}$ протягом 24-48 годин. Ріст бактерій досліджували методом мас-спектрометрії з лазерною десорбцією/ іонізацією MALDI-TOF. Мультиплексна ПЛР зразків CMP проводилася з використанням наборів для екстракції ДНК Qiagen (USA).

Результати. Із 276 досліджених зразків CMP, n'ять (1.87\%) були культуро-позитивними (три S. pneumoniae ma два зразки - E. coli). За допомогою типової ПЛР ДНК збудника було знайдено у 28 зразках (10.49\%). 3 цих 28 зразків у 20 (71.43\%) - були ідентифіковані S. pпеuтопiaе, а у 8 зразках (28.57\%) - E. coli. 
Серед зразків, де було виявлено S. рпеитопіае, 15 (53.57\%) належали дітям до 5 років. E. coli переважала у новонароджених. Чутливість та специфічність ПлР була 100\% та 95-98\% відповідно.

Висновки. Streptococcus pпеитопіае - найбільш поширений збудник бактеріального менінгіту у дітей віком до 5 років. Враховуючи результати наших досліджень, ПЛР-діагностика повинна впроваджуватися у комплекс методів діагностики гострого бактеріального менінгіту.

КЛЮЧОВІ СЛОВА: спинномозкова рідина (СМР); гострий бактеріальний менінгіт; пЛР; MALDI-TOF.

\section{Information about authors}

M. S. Raza - Ph.D, Post-Doctoral Fellow, Department of Microbiology, All India Institute of Medical Sciences, New Delhi, India

ORCID https://orcid.org/0000-0002-5787-031X, E-mail sahidktm2000@gmail.com

B. K. Das - MD, FRCP, Professor, Department of Microbiology, AIIMS, New Delhi, India

ORCID https://orcid.org/0000-0003-1970-5046, email tezpur.bimal@gmail.com

R. Chaudhry - MD, Professor, Department of Microbiology, AIIMS, New Delhi, India

ORCID https://orcid.org/0000-0002-7381-1504, email drramach@gmail.com

S. Sood - MD, Professor, Department of Microbiology, AIIMS, New Delhi, India

ORCID https://orcid.org/0000-0002-8797-5286, E-mail: seemalsood@gmail.com

A. Kapil-MD, Professor, Department of Microbiology, All India Institute of Medical Sciences, New Delhi, India

ORCID https://orcid.org/0000-0001-7834-2754, E-mail: akapilmicro@gmail.com

V. Goyal - MD. DM. Professor, Department of Neurology, AIIMS, New Delhi, India

ORCID https://orcid.org/0000-0002-7813-7117, E-mail: drvinaygoyal@gmail.com

R. Lodha -MD, Professor, Department of Pediatrics, AIIMS, New Delhi, India

ORCID https://orcid.org/0000-0003-2608-1163, E-mail rlodha1661@gmail.com

V. Sreenivas -Ph. D, Professor, Department of Biostatistics, AIIMS, New Delhi, India

ORCID https://orcid.org/0000-0001-9768-336X, E-mail vishnubhatla@gmail.com

D. Nair - MD, Professor, Department of Microbiology, VMC, Safdarjung Hospital, New Delhi, India

ORCID https://orcid.org/0000-0002-0081-4034, E-mail deepthinair2@gmail.com

H. Gautam - MD, Associate Professor, Department of Microbiology, AIIMS, New Delhi, India

ORCID https://orcid.org/0000-0002-1409-1543, E-mail drhitender@gmail.com

S. Mohapatra- MD, Associate Professor, Department of Microbiology, AIIMS, New Delhi, India

ORCID https://orcid.org/0000-0002-8311-4112, E-mail drsarita2005@gmail.com

\section{References}

1. McIntyre PB, O'Brien KL, Greenwood B, Van de Beek $D$. Effect of vaccines on bacterial meningitis worldwide. Lancet. 2012; 380:1703-11.

doi: $10.1016 /$ s0140-6736(12)61187-8

2. Kabra SK, Praveen Kumar, Verma IC, Mukherjee D, Chowdhary BH, Sengupta S, et al. Bacterial meningitis in India: An IJP survey. Indian J Pediatr. 1991;58:505-11.

doi: $10.1007 /$ bf02750932

3. Tang LM, Chen ST, Hsu WC, Lyu RK. Acute bacterial meningitis in adults: A hospital-based epidemiological study. QJM. 1999;92:719-25.

doi: 10.1093/qjmed/92.12.719

4. Ayaz C, Mehmet FG, Hosoglu S, Mustafa KC, Akalin S, Omer FK. Characteristics of acute bacterial meningitis in Southeast Turkey. Indian J Med Sci. 2004;58:327-33.

5. Chinchankar N, Mane M, Bhave S, Bapat S, Bavdekar A, Pandit A, Niphadkar KB, Dutta A, Leboulleux D. Diagnosis and outcome of acute bacterial meningitis in early childhood. Indian pediatrics. 2002 Oct 13;39(10):914-21.
6. Van de Beek D, de GansJ, Tunkel AR, Wijdicks EF. Community-acquired bacterial meningitis in adults. New England Journal of Medicine. 2006 Jan 5;354(1):44-53.

doi: 10.1056/nejmra052116

7. Schuchat A, Robinson K, Wenger JD, Harrison LH, Farley M, Reingold AL, Lefkowitz L, Perkins BA. Bacterial meningitis in the United States in 1995. New England journal of medicine. 1997 Oct 2;337(14): 970-6.

doi: 10.1056/nejm199710023371404

8. Kasanmoentalib ES, Brouwer MC, van de Beek D. Update on bacterial meningitis: epidemiology, trials and genetic association studies. Current opinion in neurology. 2013 Jun 1;26(3):282-8.

doi: $10.1097 /$ wco.0b013e328360415c

9. Liu L, Oza S, Hogan D, Perin J, Rudan I, Lawn JE, Cousens S, Mathers C, Black RE. Global, regional, and national causes of child mortality in 2000-13, with projections to inform post-2015 priorities: an updated systematic analysis. The Lancet. 2015 Jan 31;385(9966):430-40.

doi: $10.1016 / s 0140-6736(14) 61698-6$ 
10. Brouwer MC, Tunkel AR, van de Beek D. Epidemiology, diagnosis, and antimicrobial treatment of acute bacterial meningitis. Clinical microbiology reviews. 2010 Jul 1;23(3):467-92.

doi: $10.1128 / \mathrm{cmr} .00070-09$

11. Greisen K, Loeffelholz M, Purohit A, Leong D. PCR primers and probes for the 16S rRNA gene of most species of pathogenic bacteria, including bacteria found in cerebrospinal fluid. Journal of clinical microbiology. 1994 Feb 1;32(2):335-51.

doi: 10.1128/jcm.32.2.335-351.1994

12. Lu JJ, Perng CL, Lee SY, Wan CC. Use of PCR with universal primers and restriction endonuclease digestions for detection and identification of common bacterial pathogens in cerebrospinal fluid. Journal of clinical microbiology. 2000 Jun 1;38(6):2076-80.

doi: 10.1128/.38.6.2076-2080.2000

13. Rådström $P$, Bäckman A, Qian NY, Kragsbjerg $P$, Påhlson $C$, Olcén $P$. Detection of bacterial DNA in cerebrospinal fluid by an assay for simultaneous detection of Neisseria meningitidis, Haemophilus influenzae, and streptococci using a seminested PCR strategy. Journal of Clinical Microbiology. 1994 Nov 1;32(11):2738-44.

doi: $10.1128 / \mathrm{jcm} .32 .11 .2738-2744.1994$

14. Saravolatz LD, Manzor O, VanderVelde N, Pawlak J, Belian B. Broad-range bacterial polymerase chain reaction for early detection of bacterial meningitis. Clinical infectious diseases. 2003 Jan 1;36(1):40-5. doi: $10.1086 / 345438$

15. Xu J, Millar BC, Moore JE, Murphy K, Webb H, Fox AJ, Cafferkey M, Crowe MJ. Employment of broadrange $16 \mathrm{~S}$ rRNA PCR to detect aetiological agents of infection from clinical specimens in patients with acute meningitis-rapid separation of 16S rRNA PCR amplicons without the need for cloning. Journal of applied microbiology. 2003 Feb;94(2):197-206.

doi: 10.1046/j.1365-2672.2003.01839.x

16. Schuurman T, De Boer RF, Kooistra-Smid AM, Van Zwet AA. Prospective study of use of PCR amplification and sequencing of $16 \mathrm{~S}$ ribosomal DNA from cerebrospinal fluid for diagnosis of bacterial meningitis in a clinical setting. Journal of clinical microbiology. 2004 Feb 1;42(2):734-40.

doi: $10.1128 / \mathrm{jcm} .42 .2 .734-740.2004$

17. Deutch $S$, Pedersen LN, Pødenphant L, Olesen R, Schmidt MB, Møller JK, Ostergaard L. Broad-range real time PCR and DNA sequencing for the diagnosis of bacterial meningitis. Scandinavian journal of infectious diseases. 2006 Jan 1;38(1):27-35. doi: 10.1080/00365540500372861

18. Chakrabarti P, Das BK, Kapil A. Application of 16S rDNA based seminested PCR for diagnosis of acute bacterial meningitis. Indian Journal of Medical Research. 2009 Feb 1;129(2):182-8.

19. Bergh K, Stoelhaug A, Loeseth K, Bevanger L. Detection of group $B$ streptococci (GBS) in vaginal swabs using real-time PCR with TaqMan probe hybridization. Indian Journal of Medical Research. 2004 May 1;119:221-3.

20. Bonab ZH, Farajnia S, Ghotaslou R, Nikkhah E. Evaluation of nested PCR method for diagnosis of meningitis due to Neisseria meningitidis and Haemophilus influenzae. Turkish Journal of Biology. 2012 Nov 21;36(6):727-31.

21. Nigrovic LE, Malley R, Macias CG, Kanegaye JT, Moro-Sutherland DM, Schremmer RD, Schwab SH, Agrawal D, Mansour KM, BennettJE, Katsogridakis YL. Effect of antibiotic pretreatment on cerebrospinal fluid profiles of children with bacterial meningitis. Pediatrics. 2008 Oct 1;122(4):726-30.

22. Nour M, Alaidarous A. Simultaneous Detection of Bacterial Meningitis in Suspected Cases of Meningitis in Children Using PCR Assay. Arch Clin Microbiol. 2017; 8:1-6.

23. Henry M Wu, Soraia M Cordeiro, Brian H Harcourt. BMC Infectious Diseases. 2013, 13:26.

24. Camacho-Gonzalez A, Spearman PW, Stoll BJ. Neonatal infectious diseases: evaluation of neonatal sepsis. Pediatric Clinics of North America. 2013 Apr;60(2):367-89.

doi: 10.1016/j.pcl.2012.12.003

25. Chang CJ, Chang WN, Huang LT, Huang SC, Chang YC, Hung PL, Lu CH, Chang CS, Cheng BC, Lee PY, Wang KW. Bacterial meningitis in infants: the epidemiology, clinical features, and prognostic factors. Brain and development. 2004 Apr 1;26(3): 168-75.

doi: 10.1016/s0387-7604(03)00122-0

26. Manoharan A, Manchanda V, Balasubramanian S, Lalwani S, Modak M, Bai S, Vijayan A, Shet A, Nagaraj S, Karande S, Nataraj G. Invasive pneumococcal disease in children aged younger than 5 years in India: a surveillance study. The Lancet Infectious Diseases. 2017 Mar 1;17(3):305-12.

doi: 10.1016/s1473-3099(16)30466-2

27. Jayaraman $Y$, Veeraraghavan $B$, Chethrapilly PGK. Burden of bacterial meningitis in India: Preliminary data from a hospital-based sentinel surveillance network. PLoS ONE. 2018; 13(5): e0197198. doi: 10.1371/journal.pone.0197198

28. Invasive Bacterial Infection Surveillance (IBIS) group, International Clinical Epidemiology Network (INCLEN). Prospective multicentre hospital surveillance of Streptococcus pneumoniae disease in India. Lancet. 1999; 353: 1216-21.

doi: 10.1016/s0140-6736(98)07228-6

29. Sachdeva A, Kukreja S, Jain V, Dutta AK. Meningococcal disease-outbreak in Delhi. Indian Pediatrics. 2005 Jun 17;42(6):547-56.

Received 19 Mar 2020; revised 10 Apr 2020; accepted 30 May 2020.

This is open access article distributed under the Creative Commons Attribution License, which permits unrestricted use, distribution, and reproduction in any medium, provided the original work is properly cited. 